\title{
Current Evidence on Vitamin D Deficiency and Metabolic Syndrome in Obese Children: What Does the Evidence from Saudi Arabia Tell Us?
}

\author{
Asma M. Alaklabi ${ }^{1}$ and Naser A. Alsharairi ${ }^{2, *}$ \\ 1 Public Health, School of Medicine, Griffith University, Gold Coast Campus, Southport, QLD 4222, Australia; \\ asma-188@hotmail.com \\ 2 Understanding Chronic Conditions, Heart, Mind \& Body Research Group, Menzies Health Institute Queensland, \\ Griffith University, Gold Coast Campus, Southport, QLD 4222, Australia \\ * Correspondence: naser.alsharairi@gmail.com
}

Received: 11 November 2017; Accepted: 11 January 2018; Published: 15 January 2018

\begin{abstract}
Obesity and vitamin D deficiency represent major health problems among Saudi children, and have been linked to chronic diseases. Obese children are at risk of developing vitamin $\mathrm{D}$ deficiency, which appears to have negative influences on energy homeostasis, impeded bone mineralisation, insulin resistance and inflammation. Evidence supporting the association between vitamin D deficiency of obese children and metabolic syndrome has not specifically been studied in early childhood. The mechanisms through which vitamin D deficiency is associated with metabolic syndrome in obese children needs further elucidation. This commentary aims to (i) summarise current knowledge of the association between vitamin D deficiency and metabolic syndrome in obese children; and (ii) discuss current evidence for the association among Saudi Arabian children.
\end{abstract}

Keywords: children; obesity; metabolic syndrome; vitamin D; Saudi Arabia

\section{Introduction}

Vitamin D deficiency among children has become a major health problem worldwide [1]. Previous research findings have indicated that vitamin D deficiency is common among children in Western countries [2-5]. Some studies examining vitamin D deficiency in Saudi Arabia have demonstrated a high prevalence of vitamin D deficiency among children and adolescents [6,7]. Low vitamin D levels can have several causes, such as abnormal intestinal function or malabsorption, reduced intake or increased degradation of vitamin D [1].

Obesity and being overweight represent major health problems among children in Saudi Arabia [8-10]. Vitamin D deficiency was associated with obesity, but the degree of this linkage is unclear [11,12]. Vitamin D deficiency was associated with excess body weight due to vitamin D malabsorption or the sequestration of the vitamin in adipose tissue, which may therefore affect the bioavailability of fat-soluble vitamin D in obese individuals [13]. Studies have repeatedly shown that obesity is associated with vitamin D deficiency in children and adolescents [12,14-17]. Some studies have found that vitamin D deficiency was associated with obesity among Saudi adolescents $[18,19]$. However, the causality of the relationship between vitamin D deficiency and obesity in children remains uncertain.

Metabolic syndrome is a clinical condition that consists of several cardiometabolic risk factors such as obesity, hypertension, dyslipidemia, and insulin resistance that occur in obese children [20,21]. Previous research has found evidence for an association between metabolic syndrome and cardiovascular risk factors (impaired fasting glucose, low-density lipoprotein (LDL) cholesterol, hypertriglyceridemia) among Saudi children and adolescents [22]. 
Research suggests that vitamin D deficiency has been linked to metabolic syndrome [23,24]. The empirical evidence on the association between vitamin D deficiency and metabolic syndrome in obese children is inadequate and no research has been done focusing on early childhood. In addition, the mechanism through which vitamin D deficiency is associated with metabolic syndrome in obese children has not been fully elucidated. Therefore, providing evidence from studies examining whether vitamin D deficiency is associated with metabolic syndrome in obese children is crucial. The most commonly used criteria for defining metabolic syndrome in this paper require that dyslipidemia, abnormal glucose metabolism, accelerated atherosclerosis, impaired fasting glycaemia, increased homeostatic model assessment-Insulin resistance (HOMA-IR) levels, increased systolic blood pressure and low plasma adiponectin levels be present in obese children. This commentary aims to summarise current knowledge regarding the association between vitamin D deficiency and metabolic syndrome in obese children, and to discuss current evidence for the association among Saudi Arabian children.

\section{Vitamin D in Children: Assessment of Status and Deficiency Risk Factors}

Vitamin D is a fat-soluble vitamin that distributed into serum, muscle, liver and fat tissue [25]. Vitamin D is obtained from dietary sources or made in the skin when it's exposed to sun [26,27]. There are two important forms of total body vitamin D stores; vitamin D2 (ergocalciferol) and D3 (cholecalciferol). Vitamin D2 is produced via ultraviolet B (UVB) irradiated yeast and used as a dietary supplement, whereas vitamin D3 is produced in the skin in response to exposure to the sun's UV rays or obtained from dietary sources, supplements or fortified foods. Both forms are converted into $25(\mathrm{OH}) \mathrm{D}$ (calcidiol) in the liver, and then converted to the $1,25(\mathrm{OH})_{2} \mathrm{D}$ (calcitriol) in the kidneys which is the most active hormonal form of vitamin D [28].

Habitual intake of vitamin D in children can be estimated through the use of different tools, which differ depending on study resources, designs and objectives. The short food frequency questionnaire was found to be a valid and reliable tool to estimate vitamin D intake in children aged 6-14 years compared with other methods because it is inexpensive to administer and easy to use and analyse [29]. Other research has delivered similar findings, indicating that the short food frequency questionnaire was a valid tool to assess vitamin $D$ in young children aged $5-7$ years $[30,31]$. Furthermore, the assessment of vitamin $\mathrm{D}$ in clinical settings depends on measuring serum $25(\mathrm{OH}) \mathrm{D}$ (the summation of $25(\mathrm{OH}) \mathrm{D}_{3}$ plus $\left.25(\mathrm{OH}) \mathrm{D}_{2}\right)$. The best approach to assess an individual's vitamin $\mathrm{D}$ status is the vitamin D Standardization Program (VDSP). A standardised laboratory measurement of $25(\mathrm{OH}) \mathrm{D}$ is the most accurate laboratory procedure to the values obtained using reference measurement procedures measured by the National Institute of Standards and Technology (NIST) and Ghent University reference measurement systems (RMPs). The main steps to achieve standardisation are (1) develop RMS; (2) establish a traceability chain from the true 25(OH)D concentration as measured by an RMP to the research laboratory; and (3) establish and verify "end-user" test performance to develop consistency across different assays [32].

In common with most population subgroups of children, including adolescents, children aged 6-16 years were at risk of developing vitamin D deficiency [33-36]. There are potential confounding factors affecting vitamin D status, which are also known to play a role in increased risk of metabolic syndrome in children. For example, increased use of TV, video or computers [37-39], less physical activity [33,38-43], low sun exposure [33,41-44], low levels of milk consumption $[33,37,43,45]$ and high levels of soft drink consumption [45] can increase the risk of developing vitamin D deficiency in children aged 1-18 years. At age 6-16 years, children were vitamin D deficient in spring and winter [35,36,39,41,46-48] and girls were found to be more vitamin $D$ deficient than boys [33,34,36,37,48-50]. Low vitamin D status is a significant concern in children aged 3-18 years from some racial/ethnic minorities and urban communities in USA, Central and Western Europe, Southern Asia and Eastern Africa [39-41,44,45,47,48,50]. 


\section{Vitamin D Deficiency and Metabolic Syndrome Risk Factors in Obese Children}

Poor vitamin D levels appear to have a negative influence on energy homeostasis and insulin resistance in obese adolescents. The mechanism by which vitamin $\mathrm{D}$ influences these conditions in obese adolescents is poorly understood. The underlying process could involve insulin secretion by pancreatic $\beta$ cells or attenuation of inflammation [51] or sequestration and altered metabolism in adipose tissue [11,12]. Low vitamin D levels lead to decreased bioavailability of vitamin D in obese adults due to its sequestration in body fat $[13,52]$. Recent evidence has revealed that vitamin D deficiency is prevalent among obese adults, and vitamin D stores were greater in obese adults than in non-obese adults [53]. Available data suggests that vitamin D3 is present in fat tissue in larger amounts than vitamin D2 [13]. Research has found that the blood concentration of vitamin D3 was higher in obese than in non-obese adults following exposure to solar UVB. The obese adults produced more vitamin D3 due to their larger body surface available to exposure than non-obese adults [52]. There is little evidence to support the hypothesis that fat tissue and serum vitamin D concentrations are positively correlated in obese adults. The positive association is due to the fact that fat tissue is the storage site for vitamin D3. It is perhaps notable that obese adults produced enough vitamin D to raise the circulating of vitamin D3 by increasing their exposure to sunlight [54].

The etiology of metabolic syndrome is complex and can be influenced by a number of contributing factors. Metabolic syndrome is influenced by many factors such as obesity, smoking, alcohol intake, increasing age, unhealthy diet and lack of exercise [55-58]. Vitamin D deficiency can be considered as a risk factor for metabolic syndrome [59]. Previous cross-sectional studies suggest that low vitamin D levels have been linked to hypertension, obesity, high density lipoprotein, systolic blood pressure, fasting blood glucose, insulin resistance, hyperglycemia and dyslipidaemia in children [42,60-65] and adolescents [66-70].

A growing body of epidemiological studies suggests an association between vitamin D deficiency and obesity in children and adolescents $[12,14,15,38,41,44,47,48]$. However, the causality of the association has been uncertain. Low $25(\mathrm{OH}) \mathrm{D}$ levels may work as a marker rather than work as a primary influence on obesity [28]. Given that the predominant storage site for vitamin D is adipose tissue, it is most likely that the high storage capacity of vitamin $\mathrm{D}$ in obese adults leads to low $25(\mathrm{OH}) \mathrm{D}$ levels [52]. Observational studies found it difficult to prove that obesity causes vitamin D deficiency because low 25(OH)D levels might be attributed to lifestyle, socioeconomic or dietary factors (referred to as confounding variables). There are also no randomized controlled trial (RCT) studies specifically designed to assess the relationship between vitamin D deficiency and obesity in children. However, in a Mendelian randomisation meta-analysis in adults, the causality of the association between obesity and vitamin $\mathrm{D}$ deficiency is explored using a genetic variants instrument. It was stated that if low $25(\mathrm{OH}) \mathrm{D}$ levels lead to obesity, then genetic variants associated with low $25(\mathrm{OH}) \mathrm{D}$ levels should be linked to high body mass index (BMI). On the other hand, if obesity is causally associated with low 25(OH)D levels, then genetic variants associated with high BMI should be linked to low 25(OH)D levels [71]. Data from non-interventional observational trials have demonstrated no causal relationship between vitamin D deficiency and metabolic syndrome such as type 2 diabetes mellitus in children [72]. On the other hand, a mendelian randomisation analysis that combined case-control and cross-sectional datasets confirms a causal relationship between obesity and cardiometabolic risk factors (i.e., type 2 diabetes, blood pressure, blood lipids, glycemic phenotypes) in adults [73]. Therefore, it is possible that it is obesity and not vitamin D deficiency that causes metabolic syndrome in children.

Obese children were at greater risk of vitamin D deficiency and metabolic risk factors than normal weight children [15]. Previous cross-sectional studies found that low serum 25(OH)D level was associated with abnormal glucose metabolism and increased HOMA-IR levels [74-78], dyslipidemia [65], impaired fasting glycaemia [74-80], low plasma adiponectin levels [75-77], increased systolic blood pressure [74], decreased high-density lipoprotein-cholesterol [77-81] and accelerated atherosclerosis [82] in obese children aged 5-20 years when compared to normal weight children. 
No other studies have considered an association between vitamin D deficiency and metabolic syndrome in obese children prospectively.

\section{Current Evidence in Saudi Arabia}

The prevalence of obesity and overweight among children is high. Across Saudi Arabia, Central, Eastern and Northern regions reported the highest rates of obesity among children and adolescents [83-85]. The prevalence of obesity and overweight among children (aged 2-18 years) in the Eastern province is 19\% and $23.3 \%$ respectively [86]. A national survey in 2005 reported that the prevalence of obesity and overweight among children aged $5-18$ years are $10.1 \%$ and $22.4 \%$ in boys and $8.4 \%$ and $23.8 \%$ in girls respectively [87]. A recent cross-sectional data survey conducted in Riyadh, found that the prevalence of overweight and obesity among children aged $2-14$ years is $9.5 \%$ and $13.5 \%$ in boys and $14.4 \%$ and $18 \%$ in girls respectively [88]. The high prevalence of childhood obesity may result in serious health implications; diabetes mellitus, hypertension and dyslipidemia are most common in Saudi children, and can contribute to the development of metabolic syndrome [89].

Metabolic syndrome among children has become a serious health problem in the Arab Gulf countries [90-92]. It has been reported that the prevalence of metabolic syndrome among Saudi children and adolescents aged 10-18 years was $10.3 \%$ for boys and $8.1 \%$ for girls [93]. The high prevalence of metabolic syndrome among Saudi children and adolescents is attributed to increasing obesity, diabetes mellitus, dyslipidemia and high LDL cholesterol $[93,94]$. Metabolic syndrome is also attributed to physical inactivity and high levels of consumption of energy dense foods among children. Children and adolescents consume snack and fast foods and low fruit, vegetable, milk and breakfast. They were also physically inactive and spent time in sedentary behaviours such as TV watching [95-98]. The dietary intakes of adolescents aged 13-18 years typically include foods containing low levels of micronutrients such as calcium, phosphorus, potassium, vitamin D, vitamin E, selenium and manganese [99].

Vitamin D deficiency is a major health problem among Saudi Arabian children [6,7]. Evidence has demonstrated that children aged 4-18 years with vitamin D deficiency had low exposure to sunlight and were physically inactive $[100,101]$. Epidemiological evidence investigating the association between vitamin $\mathrm{D}$ status and metabolic risk factors has come from studies on adults. A study examined vitamin D deficiency associated with coronary heart disease among 130 adults (aged $19-49$ years). Vitamin D deficiency was used as having $25(\mathrm{OH}) \mathrm{D}<20 \mathrm{ng} / \mathrm{mL}$. The study found that vitamin D deficiency was associated with coronary heart disease. Results also showed that vitamin D deficiency was more common in coronary heart disease cases than in controls [102]. A recent case-control study aimed to investigate whether attitudes, behaviours and knowledge related to vitamin $\mathrm{D}$ contribute to the increased prevalence of vitamin $\mathrm{D}$ deficiency in adults aged $\geq 19$ years. The following cut-off of $25(\mathrm{OH}) \mathrm{D}$ was used to define vitamin D status: deficiency $25(\mathrm{OH}) \mathrm{D}<20 \mathrm{ng} / \mathrm{mL}$; insufficiency 10 to $<19.9 \mathrm{ng} / \mathrm{mL}$; sufficiency $\geq 20 \mathrm{ng} / \mathrm{mL}$; severe vitamin D deficiency $<10 \mathrm{ng} / \mathrm{mL}$. The study found that vitamin D deficiency was associated with low levels of knowledge about vitamin $\mathrm{D}$ and low intake of vitamin supplements [103]. One study found that vitamin D deficiency $(25(\mathrm{OH}) \mathrm{D}<37.5 \mathrm{nmol} / \mathrm{L})$ was associated with insulin resistance in obese adults aged 18-25 years [104]. To date, only limited examination has been made of the associations between the vitamin $\mathrm{D}$ status of obese children and metabolic risk factors in Saudi Arabia. The only evidence to date, to our knowledge, to have used a case control study to evaluate vitamin D status and its association with metabolic risk factors was undertaken among 120 obese and 120 non-obese children (aged 9-14 years) at King Saud Medical city. The available evidence suggests that serum 25(OH)D was positively associated with high density lipoprotein cholesterol and negatively associated with triglyceride, LDL cholesterol, fasting blood glucose and BMI. Results also showed that obese children had worse metabolic status than non-obese children [105]. Since there is limited evidence about evaluating vitamin D's effectiveness in preventing cardiovascular diseases in the field of childhood nutrition research in Saudi Arabia, a more comprehensive investigation of the association between vitamin D status and metabolic risk factors 
in obese children would be required. A better understanding of the complexity of the relationship between vitamin D status and metabolic risk factors in obese children could enable researchers to develop appropriate health promotion schemes and future interventions targeting children, aimed at increasing knowledge and awareness about the benefits of vitamin D and potentially reducing the risk of obesity and metabolic syndrome in Saudi Arabia.

\section{Conclusions}

Current cross-sectional evidence suggests that vitamin D deficiency is associated with metabolic syndrome risk factors in obese children. No evidence to date has sought to discover if there is an association in early childhood. The prevalence of vitamin D deficiency among children was found to be dependent on confounding factors such as ethnicity, sex, low physical activity, low sun exposure, increased TV watching, low milk consumption and high soft drink consumption, which are also considered to play a role in increased risk of metabolic syndrome. Prospective studies are warranted to establish whether there is a causal association between vitamin D levels and metabolic syndrome in obese children.

The prevalence of obesity has increased in Saudi Arabia at an alarming rate; as a consequence, the risk factors for developing metabolic syndrome are found to be high among children. Although obesity and metabolic syndrome risk factors are well recognised as health problems in Saudi Arabia, limited studies have been undertaken, and health strategies have been largely ignored. The mechanisms that potentially link vitamin D deficiency with metabolic syndrome risk factors in obese children are so far poorly documented and need to be elucidated through future studies, which might provide health strategies aimed at reducing the risk of obesity and metabolic syndrome among children in Saudi Arabia.

Acknowledgments: Asma Alaklabi recently completed her Master degree in public health at the school of medicine. Asma was supported by a scholarship from Saudi Government.

Author Contributions: A.M.A. conceived the idea for this study and prepared the paper draft. N.A.A. contributed to writing and critically reviewed the paper. All authors read the final manuscript and approved the contents.

Conflicts of Interest: The authors declare no conflict of interest.

\section{References}

1. Taheri, Z.; Ghafari, M.; Hajivandi, A.; Amiri, M. Vitamin D deficiency in children and adolescents; an international challenge. J. Parathyr. Dis. 2014, 2, 27-31.

2. Gordon, C.M.; Feldman, H.A.; Sinclair, L.; Williams, A.L.; Kleinman, P.K.; Perez-Rossello, J.; Cox, J.E. Prevalence of vitamin D deficiency among healthy infants and toddlers. Arch. Paediatr. Adolesc. Med. 2008, 162, 505-512. [CrossRef] [PubMed]

3. Mansbach, J.M.; Ginde, A.A.; Camargo, C.A. Serum 25-Hydroxyvitamin D levels among US children aged 1 to 11 years: Do children need more vitamin D? Pediatrics 2009, 124, 1404-1410. [CrossRef] [PubMed]

4. Munns, C.F.; Simm, P.J.; Rodda, C.P.; Garnett, S.P.; Zacharin, M.R.; Ward, L.M.; Gedds, J.; Cherian, S.; Zurynski, Y.; Cowell, C.T.; et al. Incidence of vitamin D deficiency rickets among Australian children: An Australian Paediatric Surveillance Unit study. Med. J. Aust. 2012, 196, 466-468. [PubMed]

5. Dyson, A.; Pizzutto, S.J.; Maclennan, C.; Stone, M.; Chang, A.B. The prevalence of vitamin D deficiency in children in the Northern Territory. J. Paediatr. Child Health 2014, 50, 47-50. [CrossRef] [PubMed]

6. Mansour, M.H.K.; Alhadidi, K.M. Vitamin D deficiency in children living in Jeddah, Saudi Arabia. Indian J. Endocrinol. Metab. 2012, 16, 263-269. [CrossRef] [PubMed]

7. Al-Ghamdi, A.H.; Fureeh, A.A.; Alghamdi, J.A.; Alkuraimi, W.A.; Alomar, F.F.; Alzahrani, F.A.; Alzahrani, R.A.; Alzahrani, A.A.; Alzahrani, S.A.; Alghamdi, A.M. High prevalence of vitamin D deficiency among Saudi children and adolescents with type 1 diabetes in Albaha Region, Saudi Arabia. IOSR J. Pharm. Biol. Sci. 2017, 12, 5-10. 
8. Al-Enazy, W.H.; Al-Enazy, F.S.; Al-Enazy, F.G.; Al-Qahtani, M.A. Prevalence of overweight and obesity among Saudi primary school students in Tabuk, Saudi Arabia. Int. J. Med. Sci. Public Health 2014, 3, 993-999. [CrossRef]

9. Al-Hazzaa, H.M.; Abahussain, N.A.; Al-Sobayel, H.I.; Qahwaji, D.M.; Alsulaiman, N.A.; Musaiger, A.O. Prevalence of overweight, obesity, and abdominal obesity among Urban Saudi adolescents: Gender and regional variations. J. Health Popul. Nutr. 2014, 32, 634-645. [PubMed]

10. Hammad, S.S.; Berry, D.C. The child obesity epidemic in Saudi Arabia: A review of the literature. J. Transcult. Nurs. 2016. [CrossRef] [PubMed]

11. Wojcik, M. Childhood obesity and vitamin D deficiency. J. Endocrinol. Diabetes Obes. 2013, 1, 1004.

12. Peterson, C.A. Vitamin D deficiency and childhood obesity: Interactions, implications, and recommendations. Nutr. Diet. Suppl. 2015, 2015, 29-39. [CrossRef]

13. Pramyothin, P.; Biancuzzo, R.M.; Lu, Z.; Hess, D.T.; Apovian, C.M.; Holick, M.F. Vitamin D in adipose tissue and serum 25-Hydroxyvitamin D after roux-en-Y gastric bypass. Obesity 2011, 19, 2228-2234. [CrossRef] [PubMed]

14. Au, L.E.; Rogers, G.T.; Harris, S.S.; Dwyer, J.T.; Jacques, P.F.; Sacheck, J.M. Associations of vitamin D intake with 25-Hydroxyvitamin D in overweight and racially/ethnically diverse US children. J. Acad. Nutr. Diet. 2013, 113, 1511-1516. [CrossRef] [PubMed]

15. Turer, C.B.; Lin, H.; Flores, G. Prevalence of vitamin D deficiency among overweight and obese US children. Pediatrics 2013, 131, e152. [CrossRef] [PubMed]

16. Kanddeel, W.A.; Salah, N.; Zaki, M.; Amin, A.; Ahmed, H.H.; Ismail, A.S.; Samie, O.A.; Elmalt, H. Vitamin D status and insulin resistance in obese Egyptian children. Pharm. Lett. 2016, 8, 151-160.

17. Wakayo, T.; Whiting, S.J.; Belachew, T. Vitamin D deficiency is associated with overweight and/or obesity among schoolchildren in Central Ethiopia: A cross-sectional study. Nutrients 2016, 8, 190. [CrossRef] [PubMed]

18. Al Asoom, L.I. The association of adiposity indices and plasma vitamin D in young females in Saudi Arabia. Int. J. Endocrinol. 2016, 2016, 1215362. [CrossRef] [PubMed]

19. Abdelkarem, H.M.; El-Sherif, M.A.; Gomaa, S.B. Vitamin D status and insulin resistance among young Saudi females. Saudi Med. J. 2016, 37, 561-566. [CrossRef] [PubMed]

20. Cruz, M.L.; Goran, M.I. The metabolic syndrome in children and adolescents. Curr. Diabetes Rep. 2004, 4, 53-62. [CrossRef]

21. Weiss, R.; Bremer, A.A.; Lustig, R.H. What is metabolic syndrome, and why are children getting it? Ann. N. Y. Acad. Sci. 2013, 1281, 123-140. [CrossRef] [PubMed]

22. Taha, D.; Ahmed, O.; Sadiq, B.B. The prevalence of metabolic syndrome and cardiovascular risk factors in a group of obese Saudi children and adolescents: A hospital-based study. Ann. Saudi Med. 2009, 29, 357-360. [CrossRef] [PubMed]

23. Sacheck, J.; Goodman, E.; Chui, K.; Chomitz, V.; Must, A.; Economos, C. Vitamin D deficiency, adiposity, and cardiometabolic risk in urban schoolchildren. J. Pediatr. 2011, 159, 945-950. [CrossRef] [PubMed]

24. Boucher, B.J. Is vitamin D status relevant to metabolic syndrome? Dermatoendocrinology 2012, 4, $212-224$. [CrossRef] [PubMed]

25. Walsh, J.S.; Bowles, S.; Evans, A.L. Vitamin D in obesity. Curr. Opin. Endocrinol. Diabetes Obes. 2017, 24, 389-394. [CrossRef] [PubMed]

26. Holden, J.M.; Lemar, L.E.; Exler, L. Vitamin D in foods: Development of the US Department of Agriculture database. Am. J. Clin. Nutr. 2008, 87, 1092S-1096S. [PubMed]

27. Nair, R.; Maseeh, A. Vitamin D: The "sunshine" vitamin. J. Pharmacol. Pharmacother. 2012, 3, 118-123. [PubMed]

28. Thacher, T.D.; Clarke, B.L. Vitamin D insufficiency. Mayo Clin. Proc. 2011, 86, 50-60. [CrossRef] [PubMed]

29. Nucci, A.M.; Russell, C.S.; Luo, R.; Ganji, V.; Olabopo, F.; Hopkins, B.; Holick, M.F.; Rajakumar, K. The effectiveness of a short food frequency questionnaire in determining vitamin $\mathrm{D}$ intake in children. Dermatoendocrinology 2013, 5, 205-210. [CrossRef] [PubMed]

30. Söderberg, L.; Lind, T.; Åkeson, P.K.; Sandström, A.; Hernell, O.; Öhlund, I. A validation study of an interviewer-administered short food frequency questionnaire in assessing dietary vitamin $\mathrm{D}$ and calcium intake in Swedish children. Nutrients 2017, 9, 682. [CrossRef] [PubMed] 
31. Cribb, V.L.; Northstone, K.; Hopkins, D.; Emmett, P.M. Sources of vitamin D and calcium in the diets of preschool children in the UK and the theoretical effect of food fortification. J. Hum. Nutr. Diet. 2015, 28, 583-592. [CrossRef] [PubMed]

32. Binkley, N.; Sempos, S.T.; Vitamin D Standardization Program (VDSP). Standardizing vitamin D assays. The way forward. J. Bone Miner. Res. 2014, 29, 1709-1714. [CrossRef] [PubMed]

33. Bener, A.; Al-Ali, M.; Hoffmann, G.F. High prevalence of vitamin D deficiency in young children in a highly sunny humid country: A global health problem. Minerva Pediatr. 2009, 61, 15-22. [PubMed]

34. Andıran, N.; Çelik, N.; Akça, H.; Doğan, G. Vitamin D deficiency in children and adolescents. J. Clin. Res. Pediatr. Endocrinol. 2012, 4, 25-29. [CrossRef] [PubMed]

35. Zhu, Z.; Zhan, J.; Shao, J.; Chen, W.; Chen, L.; Li, W.; Ji, C.; Zhao, Z. High prevalence of vitamin D deficiency among children aged 1 month to 16 years in Hangzhou, China. BMC Public Health 2012, 12, 126. [CrossRef] [PubMed]

36. Hu, Y.; Chen, J.; Wang, R.; Li, M.; Yun, C.; Li, W.; Yang, Y.; Piao, J.; Yang, X.; Yang, L. Vitamin D nutritional status and its related factors for Chinese children and adolescents in 2010-2012. Nutrients 2017, 9, 1024. [CrossRef] [PubMed]

37. Kumar, J.; Muntner, P.; Kaskel, F.J.; Hailpern, S.M.; Melamed, M.L. Prevalence and associations of 25-Hydroxyvitamin D deficiency in US children: NHANES 2001-2004. Pediatrics 2009, 124, e362-e370. [CrossRef] [PubMed]

38. Absoud, M.; Cummins, C.; Lim, M.J.; Wassmer, E.; Shaw, N. Prevalence and predictors of vitamin D insufficiency in children: A Great Britain population based study. PLoS ONE 2011, 6, e22179. [CrossRef] [PubMed]

39. Voortman, T.; van den Hooven, E.H.; Heijboer, A.C.; Hofman, A.; Jaddoe, V.W.; Franco, O.H. Vitamin D deficiency in school-age children is associated with sociodemographic and lifestyle factors. J. Nutr. 2015, 145, 791-798. [CrossRef] [PubMed]

40. Hintzpeter, B.; Scheidt-Nave, C.; Muller, M.J.; Schenk, L.; Mensink, G.B.M. Higher prevalence of vitamin D deficiency is associated with immigrant background among children and adolescents in Germany. J. Nutr. 2008, 138, 1482-1490. [PubMed]

41. Vierucci, F.; Del Pistoia, M.; Fanos, M.; Erba, P.; Saggese, G. Prevalence of hypovitaminosis D and predictors of vitamin D status in Italian healthy adolescents. Ital. J. Pediatr. 2014, 40, 54. [CrossRef] [PubMed]

42. Saki, F.; Dabbaghmanesh, M.H.; Omrani, G.R.; Bakhshayeshkaram, M. Vitamin D deficiency and its associated risk factors in children and adolescents in southern Iran. Public Health Nutr. 2017, 20, 1851-1856. [CrossRef] [PubMed]

43. Abu Shady, M.M.; Youssef, M.M.; Saleh El-Din, E.M.; Abdel Samie, O.M.; Megahed, H.S.; Salem, S.M.; Mohsen, M.A.; Abdel Aziz, A.; El-Toukhy, S. Predictors of serum 25-Hydroxyvitamin D concentrations among a sample of Egyptian schoolchildren. Sci. World J. 2016, 2016, 8175768. [CrossRef] [PubMed]

44. Wakayo, T.; Belachew, T.; Vatanparast, H.; Whiting, S.J. Vitamin D deficiency and its predictors in a country with thirteen months of sunshine: The case of school children in Central Ethiopia. PLoS ONE 2015, 10, e0120963. [CrossRef] [PubMed]

45. Gordon, C.M.; DePeter, K.C.; Feldman, H.A.; Grace, E.; Emans, S.J. Prevalence of vitamin D deficiency among healthy adolescents. Arch. Pediatr. Adolesc. Med. 2004, 158, 531-537. [CrossRef] [PubMed]

46. Roh, Y.E.; Kim, B.R.; Choi, W.B.; Kim, Y.M.; Cho, M.; Kim, H.; Park, K.H.; Kim, K.H.; Chun, P.; Kim, S.Y.; et al. Vitamin D deficiency in children aged 6 to 12 years: Single center's experience in Busan. Ann. Pediatr. Endocrinol. Metab. 2016, 21, 149-154. [CrossRef] [PubMed]

47. Kannan, S.; Visintainer, P.; Ganguri, H.B.; Conroy, R.; Gudala, M.; Wittcopp, C. Body mass index is a strong predictor of vitamin D deficiency in multiethnic obese children. Obes. Res. Open J. 2016, 4, 11-18. [CrossRef]

48. Durá-Travé, T.; Gallinas-Victoriano, F.; Chueca-Guindulain, M.J.; Berrade-Zubiri, S. Prevalence of hypovitaminosis D and associated factors in obese Spanish children. Nutr. Diabetes 2017, 7, e248. [CrossRef] [PubMed]

49. Neyestani, T.R.; Hajifaraji, M.; Omidvar, N.; Eshraghian, M.R.; Shariatzadeh, N.; Kalayi, A.; Gharavi, A.; Khalaji, N.; Haidari, H.; Zowghi, T.; et al. High prevalence of vitamin D deficiency in school-age children in Tehran, 2008: A red alert. Public Health Nutr. 2012, 15, 324-330. [CrossRef] [PubMed] 
50. Al-Sadat, N.; Majid, H.A.; Sim, P.Y.; Su, T.T.; Dahlui, M.; Abu Bakar, M.F.; Dzaki, N.; Norbaya, S.; Murray, L.; Cantwell, M.M.; et al. Vitamin D deficiency in Malaysian adolescents aged 13 years: Findings from the Malaysian Health and Adolescents Longitudinal Research Team study (MyHeARTs). BMJ Open 2016, 18, e010689. [CrossRef] [PubMed]

51. Peterson, C.A.; Tosh, A.K.; Belenchia, A.M. Vitamin D insufficiency and insulin resistance in obese adolescents. Ther. Adv. Endocrinol. Metab. 2014, 5, 166-189. [CrossRef] [PubMed]

52. Wortsman, J.; Matsuoka, L.Y.; Chen, T.C.; Lu, Z.; Holick, M.F. Decreased bioavailability of vitamin D in obesity. Am. J. Clin. Nutr. 2000, 72, 690-693. [PubMed]

53. Carrelli, A.; Bucovsky, M.; Horst, R.; Cremers, S.; Zhang, C.; Bessler, M.; Schrope, B.; Evanko, J.; Blanco, J.; Silverberg, S.J.; et al. Vitamin D storage in adipose tissue of obese and normal weight women. J. Bone Miner. Res. 2017, 32, 237-242. [CrossRef] [PubMed]

54. Blum, M.; Dolnikowski, G.; Seyoum, E.; Harris, S.S.; Booth, A.L.; Peterson, J.; Saltzman, E.; Dawson-Hughes, B. Vitamin D3 in fat tissue. Endocrine 2008, 33, 90-94. [CrossRef] [PubMed]

55. Booth, F.W.; Roberts, C.K.; Laye, M.J. Lack of exercise is a major cause of chronic diseases. Compr. Physiol. 2012, 2, 1143-1211. [PubMed]

56. Slagter, S.N.; Van Vliet-Ostaptchouk, J.V.; Vonk, J.M.; Boezen, H.M.; Dullaart, R.P.; Kobold, A.C.; Feskens, E.J.; Van Beek, A.P.; Van der Klauw, M.M.; Wolffenbuttel, B.H. Combined effects of smoking and alcohol on metabolic syndrome: The LifeLines cohort study. PLoS ONE 2014, 9, e96406. [CrossRef] [PubMed]

57. Lee, H.A.; Lee, W.K.; Kong, K.; Chang, N.; Ha, E.; Hong, Y.S.; Park, H. The effect of eating behavior on being overweight or obese during preadolescence. J. Prev. Med. Public Health 2011, 44, 226-233. [CrossRef] [PubMed]

58. Moreira, G.C.; Cipullo, J.P.; Ciorlia, L.A.S.; Cesarino, C.B.; Vilela-Martin, J.F. Prevalence of metabolic syndrome: Association with risk factors and cardiovascular complications in an urban population. PLoS ONE 2014, 9, e105056. [CrossRef] [PubMed]

59. Awad, A.B.; Alappat, L.; Valerio, M. Vitamin D and metabolic syndrome risk factors: Evidence and mechanisms. Crit. Rev. Food Sci. Nutr. 2012, 52, 103-112. [CrossRef] [PubMed]

60. Jang, H.B.; Lee, H.; Park, J.Y.; Kang, J.; Song, J. Association between serum vitamin D and metabolic risk factors in Korean schoolgirls. Osong Public Health Res. Perspect. 2013, 4, 179-186. [CrossRef] [PubMed]

61. Lee, S.H.; Kim, S.M.; Park, H.S.; Choi, K.M.; Cho, G.J.; Ko, B.J.; Kim, J.H. Serum 25-hydroxyvitamin D levels, obesity and the metabolic syndrome among Korean children. Nutr. Metab. Cardiovasc. Dis. 2013, 23, 785-791. [CrossRef] [PubMed]

62. Bi, X.; Tey, S.L.; Leong, C.; Quek, R.; Henry, C.J. Prevalence of vitamin D deficiency in Singapore: Its implications to cardiovascular risk factors. PLoS ONE 2016, 11, e0147616. [CrossRef] [PubMed]

63. Galunska, B.T.; Gerova, D.I.; Galcheva, S.V.; Iotva, V.M. Association between vitamin D status and obesity in Bulgarian pre-pubertal children: A pilot study. Int. J. Res. Med. Sci. 2016, 4, 361-368. [CrossRef]

64. Murni, I.K.; Sulistyoningrum, D.C.; Oktaria, V. Association of vitamin D deficiency with cardiovascular disease risk in children: Implications for the Asia Pacific Region. Asia Pac. J. Clin. Nutr. 2016, 25, S8-S19. [PubMed]

65. Erol, M.; Bostan Gayret, Ö.; Hamilçıkan, Ş.; Can, E.; Yiğit, Ö.L. Vitamin D deficiency and insulin resistance as risk factors for dyslipidemia in obese children. Arch. Argent. Pediatr. 2017, 115, 133-139. [PubMed]

66. Reis, J.P.; Von Mühlen, D.; Miller, E.R.; Michos, E.D.; Appel, L.J. Vitamin D status and cardiometabolic risk factors in the US adolescent population. Pediatrics 2009, 124, e371-e379. [CrossRef] [PubMed]

67. Ganji, V.; Zhang, X.; Shaikh, N.; Tangpricha, V. Serum 25-hydroxyvitamin D concentrations are associated with prevalence of metabolic syndrome and various cardiometabolic risk factors in US children and adolescents based on assay-adjusted serum 25-hydroxyvitamin D data from NHANES 2001-2006. Am. J. Clin. Nutr. 2011, 94, 225-233. [CrossRef] [PubMed]

68. Rafraf, M.; Hasanabadz, S.K.; Jafarabadi, A. Vitamin D status and its relationship with metabolic syndrome risk factors among adolescent girls in Boukan, Iran. Public Health Nutr. 2013, 17, 803-809. [CrossRef] [PubMed]

69. Kelishadi, R.; Ardalan, G.; Motlagh, M.E.; Shariatinejad, K.; Heshmat, R.; Poursafa, P.; Kakhri, M.; Tajadini, M.; Taslimi, M. National report on the association of serum vitamin D with cardiometabolic risk factors in the pediatric population of the Middle East and North Africa (MENA): The CASPIAN-III Study. Nutrition 2014, 30, 33-38. [CrossRef] [PubMed] 
70. Kao, K.T.; Abidi, N.; Ranasinha, S.; Brown, J.; Rodda, C.; McCallum, Z.; Zacharin, M.; Simm, P.J.; Magnussen, C.G.; Sabin, M.A. Low vitamin D is associated with hypertension in paediatric obesity. J. Paediatr. Child Health 2015, 51, 1207-1213. [CrossRef] [PubMed]

71. Vimaleswaran, K.S.; Berry, D.J.; Lu, C.; Tikkanen, E.; Pilzm, S.; Hiraki, L.T.; Cooper, J.D.; Dastani, Z.; Li, R.; Houston, D.K.; et al. Causal relationship between obesity and vitamin D status: Bi-Directional Mendelian Randomization Analysis of multiple cohorts. PLoS Med. 2013, 10, e1001383. [CrossRef] [PubMed]

72. Al-Shoumer, A.A.; Al-Essa, T.M. Is there a relationship between vitamin D with insulin resistance and diabetes mellitus? World J. Diabetes 2015, 69, 1057-1064. [CrossRef] [PubMed]

73. Emdin, C.A.; Khera, A.V.; Natarajan, P.; Klarin, D.; Zekavat, S.M.; Hsiao, A.J.; Kathiresan, S. Genetic association of waist-to-hip ratio with cardiometabolic traits, Type 2 diabetes, and coronary heart disease. JAMA 2017, 317, 626-634. [CrossRef] [PubMed]

74. Pacifico, I.; Anania, C.; Osbom, J.F.; Ferraro, F.; Bonci, E.; Olivero, E.; Chiesa, C. Low 25(OH)D $\mathrm{D}_{3}$ levels are associated with total adiposity, metabolic syndrome, and hypertension in Caucasian children and adolescents. Eur. J. Endocrinol. 2011, 165, 603-611. [CrossRef] [PubMed]

75. Roth, C.L.; Elfers, C.; Kratz, M.; Hoofnagle, A.N. Vitamin D deficiency in obese children and its relationship to insulin Resistance and adipokines. J. Obes. 2011, 2011. [CrossRef] [PubMed]

76. Olson, M.L.; Maalouf, N.M.; Oden, J.D.; White, P.C.; Hutchison, M.R. Vitamin D deficiency in obese children and its relationship to glucose homeostasis. J. Endocrinol. Metab. 2012, 97, 279-285. [CrossRef] [PubMed]

77. Kardas, F.; Kendirci, M.; Kurtoglu, S. Cardiometabolic risk factors related to vitamin D and adiponectin in obese children and adolescents. Int. J. Endocrinol. 2013, 2013. [CrossRef] [PubMed]

78. Aypak, C.; Turedi, O.; Yuce, A. The association of vitamin D status with cardiometabolic risk factors, obesity and puberty in children. Eur. J. Paedtr. 2014, 173, 367-373. [CrossRef] [PubMed]

79. Ekbom, K.; Marcus, C. Vitamin D deficiency is associated with prediabetes in obese Swedish children. Acta Paediatr. 2016, 105, 1192-1197. [CrossRef] [PubMed]

80. Nunlee-Bland, G.; Gambhir, K.; Abrams, C.; Abdul, M.; Vahedi, M.; Odonkor, W. Vitamin D deficiency and insulin resistance in obese African-American adolescents. J. Pediatr. Endocrinol. Metab. 2011, 24, 29-33. [CrossRef] [PubMed]

81. Hassan, N.E.; El-Masry, S.A.; El-Banna, R.A.; Abu Shady, M.M.; Al-Tohamy, A.; Ali, M.M.; El-Moniem, A.; Anwar, M. 25-Hydroxy vitamin D, adiponectin levels and cardiometabolic risk factors in a sample of obese children. Maced. J. Med. Sci. 2014, 7, 562-566. [CrossRef]

82. Atabek, M.E.; Eklioglu, B.S.; Akyürek, N.; Alp, H. Association between vitamin D level and cardiovascular risk in obese children and adolescents. J. Pediatr. Endocrinol. Metab. 2014, 27, 661-666. [CrossRef] [PubMed]

83. El-Hazmi, M.A.F.; Warsy, A.S. A comparative study of prevalence of overweight and obesity in children in different provinces of Saudi Arabia. J. Trop. Paediatr. 2002, 48, 172-177. [CrossRef]

84. El Mouzan, M.; Al Herbish, A.S.; Al Salloum, A.A.; Al Omar, A.A.; Qurachi, M.A. Regional variation in prevalence of overweight and obesity in Saudi children and adolescents. Saudi J. Gastroenterol. 2012, 18, 129-132. [CrossRef] [PubMed]

85. Al Shehri, A.; Al Fattani, A.; Al Alwan, I. Obesity among Saudi children. Saudi J. Obes. 2013, 1, 3-9. [CrossRef]

86. Al-Dossary, S.S.; Sarkis, P.E.; Hassan, A.; El Regal, M.E.; Fouda, A.E. Obesity in Saudi children: A dangerous reality. East. Med. Health J. 2009, 16, 1003-1008.

87. El Mouzan, M.I.; Foster, P.J.; Al Herbish, A.S.; Al Salloum, A.A.; Al Omer, A.A.; Qurachi, M.M.; Kecojevic, T. Prevalence of overweight and obesity in Saudi children and adolescents. Ann. Saudi Med. 2010, 30, $203-208$. [CrossRef] [PubMed]

88. Al Saleh, A. Prevalence's of overweight and obesity among Saudi Children. Int. J. Sci. Res. 2015, 4, 765-769.

89. Al-Agha, A.; Ocheltree, A.; Shata, N. Prevalence of hyperinsulinism, type 2 diabetes mellitus and metabolic syndrome among Saudi overweight and obese pediatric patients. Minerva Pediatr. 2012, 64, $623-631$. [PubMed]

90. Misra, A.; Khurana, L. Obesity and the metabolic syndrome in developing countries. J. Clin. Endocrinol. Metab. 2008, 93, S9-S30. [CrossRef] [PubMed]

91. Al-Isa, A.; Akanji, A.O.; Thalib, L. Prevalence of the metabolic syndrome among female Kuwaiti adolescents using two different criteria. Br. J. Nutr. 2010, 103, 77-81. [CrossRef] [PubMed]

92. Eapen, V.; Mabrouk, A.; Yousef, S. Metabolic syndrome among the young obese in the United Arab Emirates. J. Trop. Paediatr. 2010, 56, 325-328. [CrossRef] [PubMed] 
93. Al-Daghri, N.M. Extremely high prevalence of metabolic syndrome manifestations among Arab youth: A call for early intervention. Eur. J. Clin. Investig. 2010, 40, 1063-1066. [CrossRef] [PubMed]

94. Al-Daghri, N.M.; Al-Attas1, O.S.; Alokail1, M.S.; Alkharfy, K.M.; Yousef, M.; Sabico, S.L.; Chrousos, G.P. Diabetes mellitus type 2 and other chronic non-communicable diseases in the central region, Saudi Arabia (Riyadh cohort 2): A decade of an epidemic. BMC Med. 2011, 9, 76. [CrossRef] [PubMed]

95. Albin Saleh, A.A.; Alhaiz, A.S.; Khan, A.R.; Al-Quwaidhi, A.J.; Aljasim, M.; Almubarak, A.; Alqurayn, A.; Alsumaeil, M.; Al Yateem, A. Prevalence of obesity in school children and its relation to lifestyle behaviors in Al-Ahsa district of Saudi Arabia. Glob. J. Health Sci. 2017, 9, 80-98. [CrossRef]

96. Al-Hazzaa, H.M.; Abahussain, N.A.; Al-Sobayel, H.I.; Qahwaji, D.M.; Musaiger, A.O. Physical activity, sedentary behaviors and dietary habits among Saudi adolescents relative to age, gender and region. Int. J. Behav. Nutr. Phys. Act. 2011, 8, 140. [CrossRef] [PubMed]

97. Al-Hazzaa, H.M.; Al-Nakeeb, Y.; Duncan, M.J.; Al-Sobayel, H.I.; Abahussain, N.A.; Musaiger, A.O.; Lyons, M.; Collins, P.; Nevill, A. A cross-cultural comparison of health behaviors between Saudi and British adolescents living in urban areas: Gender by country analyses. Int. J. Environ. Res. Public Health 2013, 10, 6701-6720. [CrossRef] [PubMed]

98. Alghadir, A.H.; Gabr, S.A.; Iqbal, Z.A. Television watching, diet and body mass index of school children in Saudi Arabia. Paediatr. Int. 2015, 58, 290-294. [CrossRef] [PubMed]

99. AlFaris, N.A.; Al-Tamimi, J.Z.; Al-Jobair, M.O.; Al-Shwaiyat, N.M. Trends of fast food consumption among adolescent and young adult Saudi girls living in Riyad. Food Nutr. Res. 2015, 59. [CrossRef] [PubMed]

100. Al-Othman, A.; Al-Musharaf, S.; Al-Daghri, N.M.; Krishnaswamy, S.; Yusuf, D.S.; Alkharfy, K.M.; Al-Saleh, Y.; Al-Attas, O.S.; Alokail, M.S.; Moharram, O.; et al. Effect of physical activity and sun exposure on vitamin D status of Saudi children and adolescents. BMC Pediatr. 2012, 3. [CrossRef] [PubMed]

101. Almehmadi, B.M.; Fallata, E.M.; Alqahtani, S.Z.; Al-Agha, A.E. The effects of physical activity and sun exposure on vitamin D status among children from Jeddah, Saudi Arabia. J. Pediatr. Care 2016, 2. [CrossRef]

102. Aljefree, N.M.; Lee, P.; Alsaqqaf, J.M.; Ahmed, F. Association between vitamin D status and coronary heart disease among adults in Saudi Arabia: A case-control study. Healthcare 2016, 4, 77. [CrossRef] [PubMed]

103. Aljefree, N.M.; Lee, P.; Ahmed, F. Knowledge and attitudes about vitamin D, and behaviors related to vitamin D in adults with and without coronary heart disease in Saudi Arabia. BMC Public Health 2017, 17, 266. [CrossRef] [PubMed]

104. Al-Sultan, A.I.; Amin, T.T.; Abou-Seif, M.A.; Al Naboli, M.R. Vitamin D, parathyroid hormone levels and insulin sensitivity among obese young adult Saudis. Eur. Rev. Med. Pharmacol. Sci. 2011, 15, 135-147. [PubMed]

105. Alfawaz, H.A.; Abdel Megeid, F.Y. Vitamin D deficiency in obese children and its relationship to the components of the metabolic syndrome. World Appl. Sci. J. 2013, 21, 320-328. 